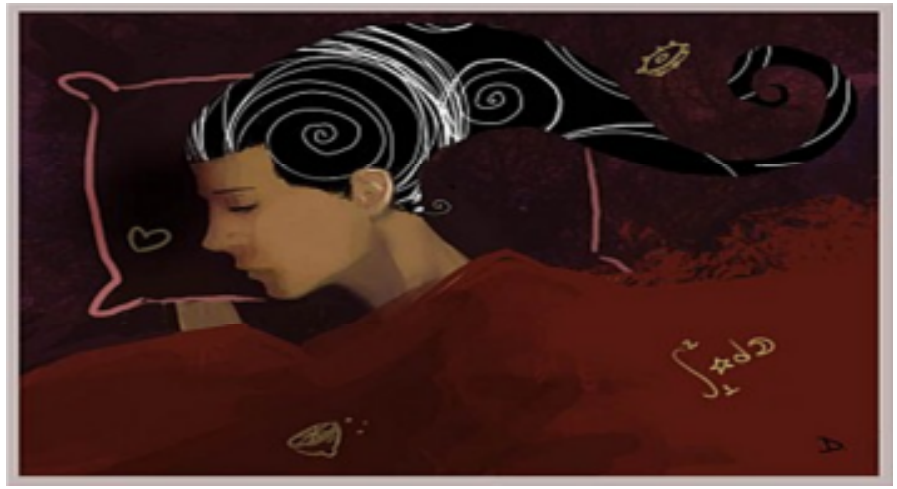

Ilustração Daniel Canelhas

\title{
Leitura na cabeça
}

\author{
Simone de Souza Gonçalves \\ por Laura Márcia Luiza Ferreira
}

Simone de Souza Gonçalves é cabeleireira há 18 anos e proprietária do Simone Hair e Cultura.

Laura Márcia Luiza Ferreira é estudante da FALE/UFMG, integrante do Programa A tela e o texto e bolsista do projeto Alfamídia.

Laura Márcia Luiza Ferreira - O Simone Hair e Cultura é um salão como qualquer outro: há pessoas cortando os cabelos, fazendo as unhas ou esperando sua vez. No entanto, enquanto as clientes esperam, é possível ler não só revistas de fofoca ou de informações como também livros de Literatura Brasileira e Estrangeira, de História da Arte e de Turismo, dentre outros. Simone, como surgiu a idéia de montar no salão uma minibiblioteca?

Simone de Souza Gonçalves - Tudo começou quando eu trabalhava em um outro salão. No intervalo entre uma cliente e outra, eu lia livros, às vezes até esquecia de ir almoçar! Quando a cliente chegava, tinha que parar de ler, mesmo querendo terminar o capítulo. E aí fiquei pensando em como fazer para que nós, que não temos acesso à cultura, tenhamos oportunidade de ler, sem precisar comprar livros. Então enquanto cortava os cabelos das clientes, conversava sobre o livro que lia, algumas vezes se interessavam e me pediam emprestado. Daí, eu comecei a trocar livros com as clientes e a incentivá-las, a colocá-los na roda. Porque temos que passar pra frente a sabedoria ao invés de deixá-la empoeirando na estante!! Eu tinha raiva de quem falava que salão é lugar de fofoca! E eu tinha certeza de que o meu salão não seria de fofoca mas sim 
de cultura. Então, fiz uma estante e coloquei na vitrine 1, 2, 3, 4.... livros, que eram meus, à disposição de quem quisesse ler. A partir daí, as clientes começaram a doar livros e hoje tenho mais de 500 títulos. Já me propuseram colocar produtos de beleza nessa estante pra vender, mas eu não abro mão dos livros!!!

Os livros ocupam um lugar de prestígio: a vitrine do salão, que normalmente é utilizada para expor produtos de beleza. Como se dá o contato com a biblioteca? Além das clientes, quem mais pode utilizar a biblioteca?

Todo mundo! Não precisa ser cliente. Há muita gente que passa em frente ao salão, olha a estante (porque os livros chamam a atenção), entra por curiosidade e se torna usuário da minibiblioteca. Quando a porta do salão está fechada, eu saio e explico que os livros são para empréstimo, basta deixar um telefone de contato.

Conte-me um pouco a respeito dos freqüentadores e dos livros que são mais lidos.

Algumas clientes conversam sobre os livros enquanto esperam: qual gostou de ler, contam a história. Às vezes, dá até discussão porque querem levar o mesmo livro para casa! o meu maior leitor é o Sr. Paulo (63), aposentado e morador do bairro. Ele está sempre vindo ao salão, pega 6 livros por semana! O meu menor leitor é um menino de 6 anos. Enquanto sua mãe corta o cabelo, ele lê gibis. A maioria gosta de ler Sidney Sheldon e Agatha Cristhie, os livros desses escritores são os mais emprestados.

Paulo Biaulas Tamietti é freqüentador da mini-biblioteca. Perguntado sobre a iniciativa de se criar uma biblioteca no salão, o sr. Paulo respondeu:

Sensacional! Chama muito a atenção, chamou a minha e a de outras pessoas. É muito raro encontrar uma biblioteca em um salão de bairro como este. Além disso, resolve o meu problema pois é complicado, pra mim, locomover-me até a rua da Bahia (onde fica a Biblioteca Central) pra pegar livros. 